\title{
PREVALENCE OF SKIN DISORDERS AMONG PRIMARY SCHOOL CHILDREN IN URBAN RAJNANDGAON (CHHATTISGARH) - A CROSS SECTIONAL STUDY
}

\author{
Vineeta Gupta1 ${ }^{1}$ Anshu Rathi², Dhiraj Bhawnani3 ${ }^{3}$ Nirmal Verma ${ }^{4}$ \\ ${ }^{1}$ Associate Professor, Department of Community Medicine, Raipur Institute of Medical Sciences, Godhi, Raipur, Chhattisgarh. \\ ${ }^{2}$ Assistant Professor, Dept. of Dermatology, Venereology and Leprology, Raipur Institute of Medical Sciences, Raipur, Chhattisgarh. \\ ${ }^{3}$ Assistant Professor, Department of Community Medicine, Government Medical College, Rajnandgaon, Chhattisgarh. \\ 4 Professor, Department of Community Medicine, Government Medical College, Rajnandgaon, Chhattisgarh.
}

\section{ABSTRACT}

\section{BACKGROUND}

Children are more prone to develop skin diseases. Contact between classmates is an important cause of skin infection and infestation among school children. School survey is a useful tool to detect prevalence of various skin diseases, status of health and hygiene of society. Assessment of the burden and pattern of skin diseases at school may improve care of children through school health programme.

\section{MATERIALS AND METHODS}

This was a cross sectional school based study conducted in urban area of Rajnandgaon (Chhattisgarh) India. Children were clinically examined by a team of doctors. 1047 students present at the time of survey out of 1209 enrolled in class I to Class V were examined. Data obtained was tabulated and analysed statistically using chi-square test.

\section{RESULTS}

Total 1047 students were examined. Of these 460 (44\%) were girls and 587 (56\%) were boys. 712 (68\%) were of 4-7 years age, and 335 (32\%) of 8-12 years. Total $43.46 \%$ students were having one or more skin problems. Pediculosis capitis, pityriasis alba, and phrynoderma were the commonest problems. Other common skin disorders were bacterial infections, scabies, fungal infections and angular cheilitis/stomatitis. Infections (bacterial and fungal) accounted for $22.91 \%$ and infestations (pediculosis and scabies) for $21.47 \%$ of total skin disorders. Difference between boys and girls was not significant. The prevalence of skin disorders is significantly higher in children of 8-12 years as compared to 4-7 years.

\section{CONCLUSION}

High prevalence of skin disorders was noted among primary school children in our area. Older age group (9-12 years) children were affected more than the younger ones (5-8 years). Pityriasis alba and phrynoderma affected boys more than the girls, whereas female preponderance was seen for pediculosis capitis, bacterial infections and milia. Transmissible disorders, constituted around $40 \%$ of total skin diseases burden. Educating children to improve their hygiene may bring down the prevalence of transmissible diseases among them.

\section{KEYWORDS}

Skin Diseases, Primary School Children, Skin Disorders.

HOW TO CITE THIS ARTICLE: Gupta V, Rathi A, Bhawnani D, et al. Prevalence of skin disorders among primary school children in urban Rajnandgaon (Chhattisgarh) - A cross sectional study. J. Evolution Med. Dent. Sci. 2017;6(9):690-693, D0I: $10.14260 /$ Jemds/2017/149

\section{BACKGROUND}

Children are more prone to develop skin diseases. Contact between classmates is an important cause of skin infection and infestation among school children. ${ }^{1}$ Skin diseases are a major health problem in the paediatric age group and are associated with significant morbidity. Skin diseases constitute $30 \%$ of all outpatient visits to a paediatrician, and $30 \%$ of all visits to a dermatologist involve children. 2,3

Financial or Other, Competing Interest: None.

Submission 23-11-2016, Peer Review 14-01-2017,

Acceptance 20-01-2017, Published 30-01-2017.

Corresponding Author:

Dr. Vineeta Gupta,

Flat No. 5 B,

$2^{\text {nd }}$ Block,

Kubher Enclave,

Junwani Road,

Kohka, Bhilai, Chhattisgarh.

E-mail: drvineetaomar@gmail.com

DOI: $10.14260 /$ jemds $/ 2017 / 149$
Paediatric dermatoses require a separate view from adult dermatoses as there are important differences in clinical presentation, treatment and prognosis. Dermatoses in children are more influenced by socioeconomic status, climatic exposure, dietary habits and external environment as compared to adults. Cutaneous infections are common in children during school going years. Some of the common skin disorders seen in children are viral warts, alopecia areata, pityriasis alba, acne, atopic dermatitis, eczema, psoriasis, phrynoderma, scabies, impetigo, dermatophyte infections, and secondary bacterial infection like folliculitis. 4 The prevalence and pattern of skin diseases varies with socioeconomic and cultural factors which in turn are related to hygiene and treatment seeking behaviour. ${ }^{5}$ Most of the skin problems though chronic are nonlethal, hence often neglected by families that is further worsened by poor health care access.

School survey is a useful yardstick as it is easy to conduct, less time consuming and large number of children of 
particular age group can be screened for presence of disease at a time. ${ }^{6}$ It is also a useful tool to detect prevalence of various skin diseases and status of health and hygiene of society. ${ }^{7}$ Assessment of the burden and pattern of skin diseases at school may improve care of children through school health programmes. ${ }^{5}$ Health education on nutrition and personal hygiene can help improve health status of school going children.

With the above background, the present study was conducted to assess the prevalence of skin disorders among primary school children.

\section{MATERIALS AND METHODS}

This was a cross sectional study conducted from September 2015 to November 2015 in urban area of Rajnandgaon (Chhattisgarh), India. Three government and two public schools were randomly selected within $5 \mathrm{~km}$ range from Government Medical College, Rajnandgaon. Study was carried out with due approval of college ethical committee. Only primary class students (from class I to class V) were included in our study. Parents of children were informed through the teachers one week prior to the study. Only those children whose parents gave written consent were examined. Total 1051 children were examined clinically by a team of doctors including a dermatologist. Out of them, 4 children aged $>12$ years were excluded from the study, thus obtained a sample size of 1047 children. Efforts were made to ensure privacy and proper lighting at the time of clinical examination. No investigation was done at school premises. All children who needed to be investigated were referred to Government Medical College Hospital, Rajnandgaon with referral slips. To other affected children prescription and instructions slips were given to the teachers. Data was tabulated and checked for its completeness and correctness. Data was analysed by using statistical test (chi-square test). The $\mathrm{p}$ value of $<0.05$ was considered statistically significant.

\section{RESULTS}

As shown in Table 1, total 1047 students were included in the present study, to assess the prevalence of skin disorders among them. Age of these students ranged between 5-12 years. Only $51(4.88 \%)$ were aged 12 whereas $92(8.78 \%)$ were 5 at the time of study. For the convenience of analysis, we grouped children in two age groups i.e. 5-8 years and 912 years. We found that 712 (68\%) children were 5-8 years of age, and 335 (32\%) were 9-12 years. Of these 460 (44\%) were girls and 587 (56\%) were boys.

\begin{tabular}{|c|c|c|}
\hline \multirow{2}{*}{ Age (Years) } & \multicolumn{2}{|c|}{ Gender } \\
\cline { 2 - 3 } & Boys & Girls \\
\hline 5 to 8 & 395 & 317 \\
\hline 9 to 12 & 192 & 143 \\
\hline Total & $\mathbf{5 8 7}$ & $\mathbf{4 6 0}$ \\
\hline Table 1. Age and Sex wise Distribution of Study Subjects \\
\hline
\end{tabular}

Out of 1047 students, 466 were noted to have one or more skin problem. Thus, overall prevalence of skin disorders among primary students was calculated as $44.50 \%$.

\begin{tabular}{|c|c|}
\hline Students with Skin Problems & No. of Students (\%) \\
\hline No Skin Problems & $581(55.49)$ \\
\hline 1 Skin Problem & $315(30.09)$ \\
\hline 2 Skin Problems & $135(12.89)$ \\
\hline >2 Skin Problems & $16(1.53)$ \\
\hline Table 2. Distribution of Study Subjects as per \\
Number of Skin Problems They Suffered \\
\hline
\end{tabular}

As given in Table 2, among 466 students, 315 (30.09\%) had only one skin problem, whereas 151 (14.42\%) had two or more lesions at the time of examination. 581 (55.49\%) children were not affected by any skin disease.

\begin{tabular}{|c|c|c|}
\hline Diagnosis & No. & \% \\
\hline Pediculosis capitis & 76 & 11.97 \\
\hline Pityriasis alba & 132 & 20.79 \\
\hline Phrynoderma & 125 & 19.69 \\
\hline Scabies & 37 & 5.83 \\
\hline Bacterial Infection & 108 & 17.01 \\
\hline Fungal infection & 35 & 5.51 \\
\hline Angular cheilitis/Stomatitis & 32 & 5.04 \\
\hline Nevi & 22 & 3.46 \\
\hline Atopic dermatitis & 21 & 3.31 \\
\hline Milia & 18 & 2.83 \\
\hline Alopecia areata & 9 & 1.42 \\
\hline Warts & 5 & 0.79 \\
\hline Vitiligo & 3 & 0.47 \\
\hline Contact dermatitis & 3 & 0.47 \\
\hline Acne & 2 & 0.31 \\
\hline Others & 7 & 1.10 \\
\hline Total diagnoses & $\mathbf{6 3 5}$ & $\mathbf{1 0 0 . 0 0}$ \\
\hline Table 3. Distribution of Various Skin \\
Disorders among Primary School Students \\
\hline \multicolumn{2}{|c|}{}
\end{tabular}

Table 3 shows distribution of skin disorders among study subjects. A total of 635 diagnoses were made from 1047 children. Most common skin problems found in our study were pityriasis alba, phrynoderma and pediculosis capitis, which contributed $20.79 \%, 19.69 \%$ and $11.19 \%$ respectively. Collectively, these three problems accounted for more than half of the total burden of skin diseases of our study subjects. Other important skin disorders noted were bacterial infections, scabies, fungal infections and angular cheilitis/stomatitis which contributed for $17.01 \%$, 5.83\%, $5.51 \%$ and $5.04 \%$ of total diagnoses respectively.

Transmissible disorders were found responsible for a fair number of disease burden. Infections (bacterial infections and fungal infections) accounted for $22.52 \%$ and infestations (pediculosis capitis and scabies) for $17.80 \%$ of total skin disorders found among the study subjects. Thus, transmissible disorders formed $40.32 \%$ of total skin problems observed in this study.

Other problems noted were nevi (3.46\%), atopic dermatitis $(3.31 \%)$, milia $(2.83 \%)$, alopecia areata $(1.42 \%)$, warts $(0.79 \%)$, vitiligo $(0.47 \%)$, and contact dermatitis $(0.47 \%)$ in children. Only 2 cases of acne vulgaris were found. Both were girls from older age group. Single cases and doubtful diagnoses were grouped as "other" category. Birth marks were not included for analysis. 


\begin{tabular}{|c|c|c|c|c|c|}
\hline \multirow{2}{*}{ Diagnosis } & \multicolumn{2}{|c|}{ Boys } & \multicolumn{2}{c|}{ Girls } & p \\
\cline { 2 - 5 } & No. & $\mathbf{\%}$ & No. & $\mathbf{\%}$ & value \\
\hline Pediculus capitis & 12 & 2.04 & 64 & 13.91 & $<0.001$ \\
\hline Pityriasis alba & 92 & 15.67 & 40 & 8.70 & $<0.001$ \\
\hline Phrynoderma & 84 & 14.31 & 41 & 8.91 & 0.0075 \\
\hline Scabies & 24 & 4.09 & 13 & 2.83 & 0.2722 \\
\hline Bact. Infection & 45 & 7.67 & 63 & 13.70 & 0.0015 \\
\hline Fungal infection & 21 & 3.58 & 14 & 3.04 & 0.6333 \\
\hline Naevi & 13 & 2.21 & 9 & 1.96 & 0.7266 \\
\hline Atopic dermatitis & 11 & 1.87 & 10 & 2.17 & 0.7311 \\
\hline Milia & 2 & 0.34 & 16 & 3.48 & $<0.001$ \\
\hline Alopecia areata & 5 & 0.85 & 4 & 0.87 & 0.9753 \\
\hline Warts & 4 & 0.68 & 1 & 0.22 & 0.2797 \\
\hline $\begin{array}{c}\text { Angular cheilitis/ } \\
\text { stomatitis }\end{array}$ & 13 & 2.21 & 19 & 4.13 & 0.0739 \\
\hline Vitiligo & 1 & 0.17 & 2 & 0.43 & 0.4269 \\
\hline Acne & 0 & 0.00 & 2 & 0.43 & 0.1146 \\
\hline Contact dermatitis & 2 & 0.34 & 1 & 0.22 & 0.711 \\
\hline Others & 5 & 0.85 & 2 & 0.43 & 0.4112 \\
\hline Table 4. Prevalence of Various Skin \\
\hline Disorders among Boys and Girls \\
\hline
\end{tabular}

Prevalence of skin disorders among boys and girls are shown in Table 4 . The overall prevalence rate for skin disorders was calculated as $56.90 \%$ in boys and $65.43 \%$ in girls. The difference in prevalence was not found significant. $\left(\chi^{2}=2.653, p>0.05\right)$.

While on analysing various skin problems separately, the difference in prevalence between boys and girls was found significant for pediculosis capitis $\left(\chi^{2}=53.9659, p<0.001\right)$, phrynoderma $\left(\chi^{2}=11.3951, \mathrm{p}<0.001\right)$, pityriasis alba $\left(\chi^{2}=\right.$ 7.1451, $\mathrm{p}=0.0075)$, bacterial infections $\left(\chi^{2}=10.135, \mathrm{p}\right.$ $=0.0015)$, and milia $\left(\chi^{2}=15.0257, p<0.001\right)$. Pediculosis capitis, bacterial infections, and milia were more prevalent in girls, whereas boys were more affected by pityriasis alba and phrynoderma.

\begin{tabular}{|c|c|c|c|c|c|}
\hline \multirow{2}{*}{ Diagnosis } & \multicolumn{2}{|c|}{5 - 8 years } & \multicolumn{2}{|c|}{$9-12$ years } & \multirow{2}{*}{ p value } \\
\hline & No. & $\%$ & No. & $\%$ & \\
\hline Pediculus capitis & 39 & 5.48 & 37 & 11.04 & 0.0012 \\
\hline Pityriasis alba & 29 & 4.07 & 103 & 30.75 & $<0.001$ \\
\hline Phrynoderma & 53 & 7.44 & 72 & 21.49 & $<0.001$ \\
\hline Scabies & 16 & 2.25 & 21 & 6.27 & 0.001 \\
\hline Bact. Infection & 66 & 9.27 & 42 & 12.54 & 0.1049 \\
\hline Fungal infection & 20 & 2.81 & 15 & 4.48 & 0.1612 \\
\hline Naevi & 9 & 1.26 & 13 & 3.88 & 0.0059 \\
\hline Atopic dermatitis & 10 & 1.40 & 11 & 3.28 & 0.0411 \\
\hline Milia & 3 & 0.42 & 15 & 4.48 & $<0.001$ \\
\hline Alopecia areata & 5 & 0.70 & 4 & 1.19 & 0.4214 \\
\hline Warts & 0 & 0.00 & 5 & 1.49 & 0.0012 \\
\hline $\begin{array}{l}\text { Angular cheilitis/ } \\
\text { stomatitis }\end{array}$ & 19 & 2.67 & 13 & 3.88 & 0.2879 \\
\hline Vitiligo & 1 & 0.14 & 2 & 0.60 & 0.1973 \\
\hline Acne & 0 & 0.00 & 2 & 0.60 & 0.039 \\
\hline $\begin{array}{c}\text { Contact } \\
\text { dermatitis }\end{array}$ & 1 & 0.14 & 2 & 0.60 & 0.1995 \\
\hline \multirow[t]{2}{*}{ Others } & 4 & 0.56 & 3 & 0.90 & 0.5365 \\
\hline & $n=712$ & & $n=335$ & & \\
\hline
\end{tabular}

Table 5 shows age wise prevalence of skin disorders in present study. The overall prevalence of skin disorders was found higher in children of 9-12 years as compared to 5-8 years. This difference was found highly significant when tested statistically. $(\chi 2=24.6528, \mathrm{p}<0.001)$

On analysing individual diseases separately, many skin problems showed higher prevalence rate in older age group. On analysing the difference in prevalence rate between the two age groups, significant difference was computed in pediculosis capitis $\left(\chi^{2}=10.4887, p=0.0012\right)$, pityriasis alba $\left(\chi^{2}=13.0122, \mathrm{p}<0.001\right)$, phrynoderma $\left(\chi^{2}=42.7665, \mathrm{p}\right.$ $<0.001)$, scabies $\left(\chi^{2}=10.8073, p=0.001\right)$., nevi $\left(\chi^{2}=7.582\right.$, $p$ $=0.0059)$., atopic dermatitis $\left(\chi^{2}=4.0926, p=0.0431\right)$, milia $\left(\chi^{2}\right.$ $=22.1838, \mathrm{p}=<0.001)$, warts $\left(\chi^{2}=10.5206, \mathrm{p}=0.0012\right)$., and acne $\left(\chi^{2}=4.2589, p=0.039\right)$.

For all these skin problems, the older age group is affected more than the younger age group. None of the disease showed significant affection towards younger age group.

\section{DISCUSSION}

School survey is a useful parameter to screen large number of children of particular age group for presence of disease. These surveys are easy to conduct, less time consuming but may not be representative of true prevalence and incidence of a disease in the community especially in a country like India, as fair number of children do not go to school.

The pattern of skin diseases in India is influenced by the developing economy, level of literacy, social backwardness, varied climate, industrialisation, access to primary health care, and different religious, ritual and cultural factors. ${ }^{8}$

The prevalence of skin disorders among students was calculated as $44.50 \%$ in our study. While in other studies it is found as $76.65 \%, 53.6 \%, 69.38 \%$, and $69.0 \%$, by Kuruvilla, ${ }^{9}$ Vallia, ${ }^{10}$ Yaseen, ${ }^{11}$ and Suman Saurabh, ${ }^{5}$ respectively in school children. This might be because students in our study belong to urban area whereas these study subjects came from rural background. In Rita Vora's ${ }^{12}$ study, semiurban population were examined and they found overall prevalence as $15.14 \%$.

In our study, transmissible skin disorders were responsible for $40.32 \%$ of total skin disease burden whereas Suman Saurabh ${ }^{5}$ observed it $71.2 \%$, Vallia 10 43\%, K.S. Negi ${ }^{1}$ $50.9 \%$, Kuruvilla ${ }^{9} 42.68 \%$, and Rita Vora's ${ }^{12} 18.14 \%$ in their studies. The difference in hygienic status, socioeconomic status and background (rural or urban) of the subjects of these studies could be the possible cause of variation of prevalence of transmissible disorder found by these researchers.

Pediculosis, Phrynoderma and P-alba were the most common disorders found. Only these three problems accounted for $51.62 \%$ of total diagnoses made. Suman Saurabh 5 also found pediculosis a major skin problem in their study subjects, in whom pediculosis, pyoderma and scabies constituted $77 \%$ of total diagnoses. P-alba was found among the 3 most common skin problems by Anand et al,13 Rita Vora et al ${ }^{11}$ and Valia et al. ${ }^{9}$

In our study, we found significantly higher prevalence of skin diseases in 9-12 year age group as compared to 5-8 year age group students. Yaseen and Hassan ${ }^{10}$ and Suman Saurabh $^{5}$ also got similar findings in their study where prevalence in 9-14 years and 9-10 years age group students respectively were found higher. 
No sex preponderance was found for overall prevalence rate, though on analysing various disorders separately, pityriasis alba and phrynoderma showed male preponderance; and pediculosis capitis, bacterial infections and milia showed female preponderance.

\section{CONCLUSION}

Skin diseases in the paediatric population are common all over the world. Similarly, we found a high prevalence of skin disorders among primary school children in our area. Pediculosis, Phrynoderma and Pityriasis alba were the most common disorders found among students of our study. In accordance with other studies, we too observed that the older age group ( $9-12$ years) is affected more than the younger ones (5-8 years). While pityriasis alba and phrynoderma showed male preponderance, female preponderance was seen in pediculosis capitis, bacterial infections and milia.

As a high prevalence and variation in the pattern of paediatric dermatoses found all over the country, there is an obvious need for diagnostic and therapeutic training for dermatologists, general practitioners and paediatricians in this group of disorders.

Transmissible disorders, constituted around $40 \%$ of total skin disease burden in the subjects of present study. Educating children to improve their hygienic status might have beneficial consequences to bring down the prevalence of transmissible diseases among them and this can be easily carried out at school level. Nutritional deficiencies were also noted in a significant number of students and hence cannot be overlooked. Strengthening of School Health Services and educating children for eating healthy food could contribute to improve health status of children. Regularity of distribution of iron-folic acid and periodic deworming of school children at schools under Rashtriya Bal Swasthya Karyakram should be ensured. Also, supply of standardised and good quality food should be taken care of by the government.

\section{REFERENCES}

[1] Negi KS, Kandpal SD, Prasad D. Pattern of skin diseases in children in Garhwal region of Uttar Pradesh. Indian Paediatrics 2001;38(1):77-80.
[2] Thappa DM. Common skin problems in children. In J Pediatr 2002;69(8):701-06.

[3] Federman DG, Reid MC, Feldman SR, et al. The primary care provider and the care of skin disease. Arch Dermatol 2001;137(1):25-9.

[4] Sharma NK, Garg BK, Goel M. Pattern of skin diseases in urban school children. Ind J Dermatol Venereol Leprol 1986;52(6):330-1.

[5] Saurabh S, Sahu SK, Sadishkumar A, et al. Screening for skin diseases among primary school children in rural area of Puducherry. IJDVL 2013;79(2):268-70.

[6] Rao GS, Kumar P, Kuruvilla M. Prevalence of various dermatoses in school children. IADVL 1999;65(3):1267.

[7] Sharma NL, Sharma RC. Prevalence of dermatological diseases in school children of a high altitude tribal area of Himachal Pradesh. IJDVL1990;56(5):375-6.

[8] Grover S, Ranyal RK, Bedi MK. A cross section of skin diseases in rural Allahabad. Indian Journal of Dermatology 2008;53(4):179-81.

[9] Kuruvilla M, Sridhar KS, Kumar P, et al. Pattern of skin diseases in Bantwal Taluk, Dakshina Kannada. IADVL 2000;66(5):247-8.

[10] Valia RA, Pandey SS, Kaur P, et al. Prevalence of skin diseases in Varanasi School children. IADVL 1991;57(3):141-3.

[11] Yaseen U, Hassan I. Prevalence of various skin disorders in school going children of Kashmir Valley of North India: a Cross sectional study. Indian Journal of Paediatric Dermatology 2013;14(3):67-72.

[12] Vora R, Bodiwala N, Patel S. Prevalence of various dermatoses in school children of Anand District. National Journal of Community Medicine. 2012;3(1):100-103.

[13] Anand BK, Marwaha MPS, Prakash B, et al. Prevalence of skin disorders in school children. Internet Journal of Health 2012;13(1):1-4. 